\title{
(200) 8.290
}

UNITED STATES DEPARTMENT OF THE INTERIOR

GEOLOGICAL SURVEY

GEOLOGICAL AND OPERATIONAL SUMMARY,

ATLANTIC RICHFIELD NORTHERN GULF OF ALASKA

COST WELL NO. 1

By J. G. Bolm, F. B. Chmelik, G. H. Stewart,

R. F. Turner, H. H. Waetjen, and J. C. Wills

E FRER E. RASNHUSON UIBRH. VERSIN OF ALASKA

$2: 0,00: 975$ emver

Open-File Report 76-635

1976

RASMUSON LIBRARY UNIVERSITY OF ALASKA-FAIRBANKS

This report has not been edited for conformity with Geological Survey editorial standards or stratigraphic nomenclature. 


\section{CONTENTS}

\section{Page}

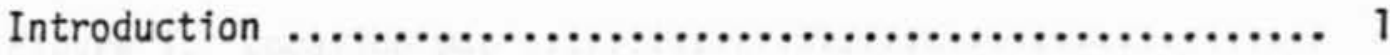

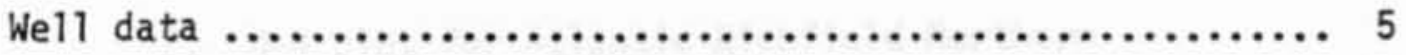

Summary of well data $\ldots \ldots \ldots \ldots \ldots \ldots \ldots \ldots \ldots \ldots \ldots, 5$

Operational data $\ldots \ldots \ldots \ldots \ldots \ldots \ldots \ldots \ldots \ldots \ldots \ldots \ldots \ldots, 8$

Operational problems $\ldots \ldots \ldots \ldots \ldots \ldots \ldots \ldots \ldots \ldots \ldots \ldots, 9$

Rock characteristics and geophysical log interpretation ...... 12

Reservoir characteristics $\ldots \ldots \ldots \ldots \ldots \ldots \ldots \ldots \ldots \ldots \ldots, 13$

Lithology crossplots $\ldots \ldots \ldots \ldots \ldots \ldots \ldots \ldots \ldots \ldots \ldots \ldots \ldots \ldots \ldots, 16$

Geothermal gradient $\ldots \ldots \ldots \ldots \ldots \ldots \ldots \ldots \ldots \ldots \ldots \ldots \ldots \ldots \ldots \ldots \ldots, 19$

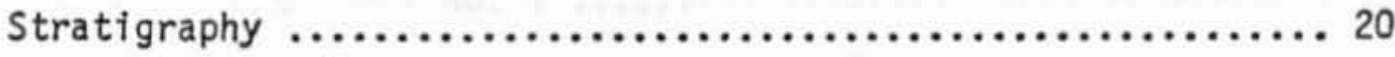

Lithologic description $\ldots \ldots \ldots \ldots \ldots \ldots \ldots \ldots \ldots \ldots \ldots \ldots \ldots \ldots \ldots \ldots \ldots \ldots, 21$

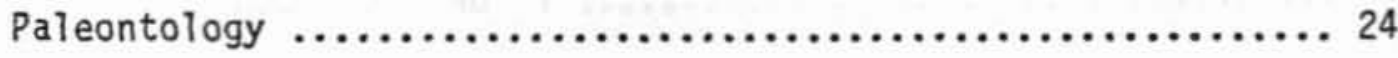

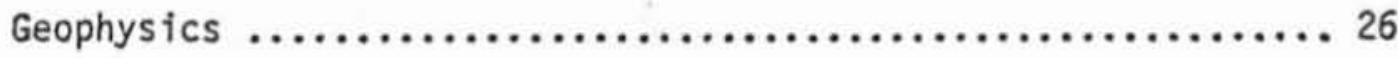

Environmental considerations $\ldots \ldots \ldots \ldots \ldots \ldots \ldots \ldots \ldots \ldots \ldots \ldots \ldots \ldots \ldots \ldots \ldots, 28$

Summary and conclusions $\ldots \ldots \ldots \ldots \ldots \ldots \ldots \ldots \ldots \ldots, \ldots \ldots \ldots, 32$

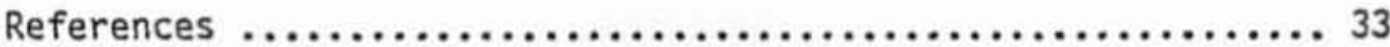




\section{ILLUSTRATIONS}

Page

Figure 1. Location map $\ldots \ldots \ldots \ldots \ldots \ldots \ldots \ldots \ldots \ldots \ldots \ldots, 3$

2. $M-N$ plot for Atlantic Richfield Northern Gulf of Alaska COST Well No. 1 ................ 14

3. Neutron-density crossplot for Atlantic Richfield Northern Gulf of Alaska COST Well No. 1 ......... 15

4. Velocity derived from sonic log for Richfield Northern Gulf of Alaska COST Well No. 1 . 27

\section{TABLES}

Table 1. MID lithology crossplot data for Atlantic Richfield Northern Gulf of Alaska COST Well No. 1

2. Calculated lithology crossplot data for Atlantic Richfield Northern Gulf of Alaska COST Well No. 1 


\section{Geological and Operation Summary, Atlantic Richfield Northern Gulf of Alaska COST Well No. 1}

By J. G. Bolm, F. B. Chmelik, G. H. Stewart, R. F. Turner, H. H. Waetjen, and J. C. Wills

\section{INTRODUCTION}

This open-file report is presented in accordance with regulations which require that geophysical and geological data and processed information acquired from deep stratigraphic test wells on the Outer Continental Shelf (OCS) be made available for public inspection following the issuance of the first Federal lease within 50 geographic (nautical) miles $(92.6 \mathrm{~km})$ of the drill site. Tracts within 50 geographic miles of the site of the Atlantic Richfield Northern Gulf of Alaska COST Well No. 1 were offered for sale in OCS Lease Sale No. 39 on April 13, 1976, and the first leases became effective June 1, 1976.

The following data are available for public inspection at the office of the $0 i 1$ and Gas Supervisor, Conservation Division, U. S. Geological Survey, 800 "A" St., Anchorage, Alaska 99501.

\section{Logs:}

Dual induction laterolog with S.P.

Borehole compensated sonic log

Compensated neutron log--density with gamma ray

Saraband sandstone analysis

Mud $\log$ 


\section{Geological and biological data:}

Well cuttings

Geochemical analysis of cuttings

Elemental analysis of cuttings

Vitrinite reflectance analysis

Biological site survey

Operational data:

Well completion report

Well history

The Atlantic Richfield Northern Gulf of Alaska COST Well No. 1, which will be referred to generally as "the COST well" hereafter, was drilled on OCS Lease Tract 196, Block 1382N - 76E, OCS Map 7-1 (Icy Bay), in 570 feet $(174 \mathrm{~m}$ ) of water approximately 29 (statute) miles $(46 \mathrm{~km})$ southwest of Cape Yakataga, Alaska, 19 miles $(30 \mathrm{~km})$ from shore (fig. 1). The site is approximately 3 miles ( $5 \mathrm{~km}$ ) from Tract 241, which was leased in the April 13, 1976, sale.

The COST well was drilled as a deep stratigraphic test to acquire information on the structure, stratigraphy, and geochemistry of the unexplored area. Twenty-six companies shared the costs of drilling; Atlantic Richfield Company served as operator for the group. The U. S. Geological Survey received geological information from this we11, as required by the permit.

On July 18, 1975, Atlantic Richfield Company was issued the final permit to dri11 a 16,500 -foot $(5,029 \mathrm{~m})$ deep stratigraphic 


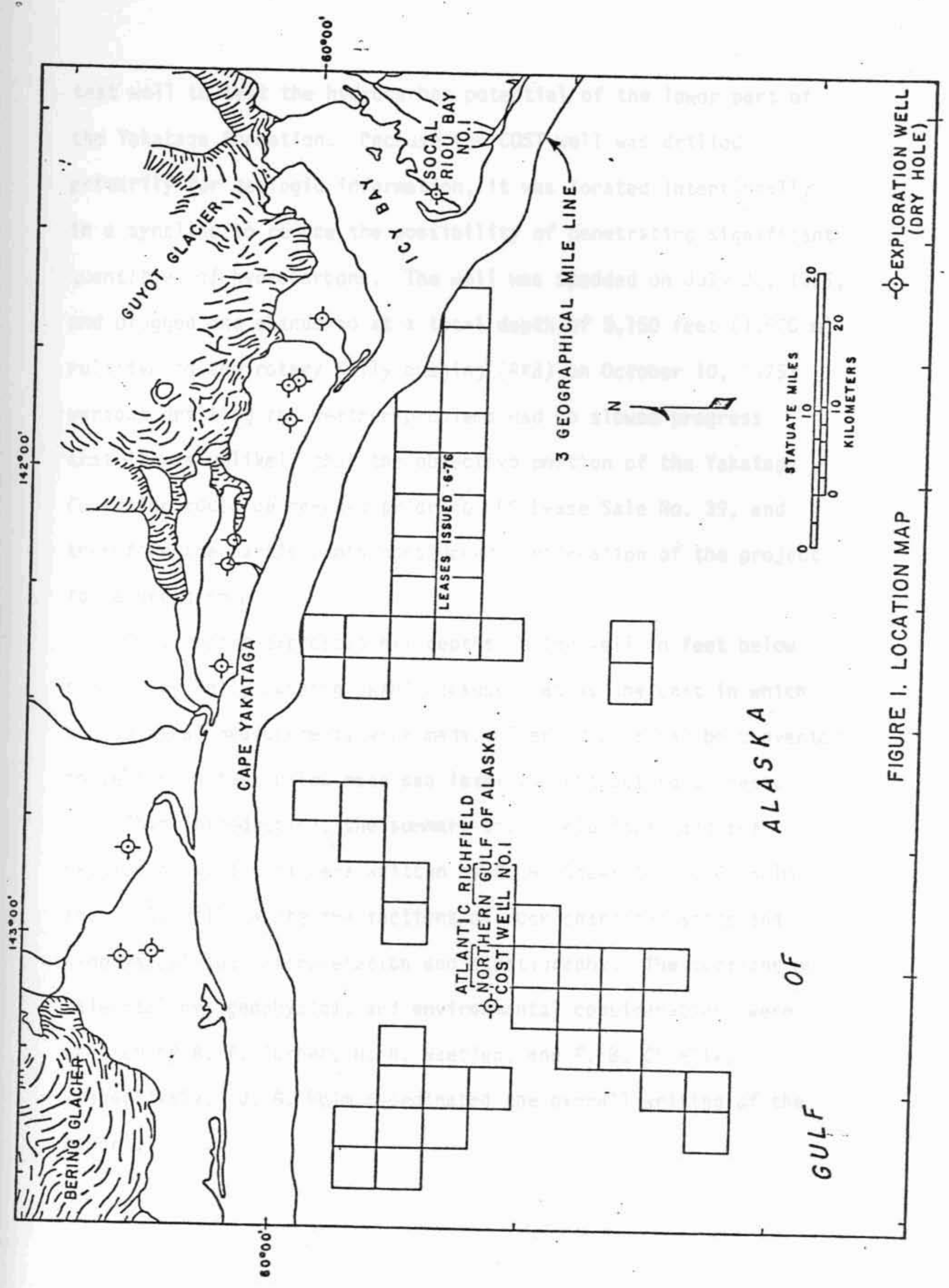


test well to test the hydrocarbon potential of the lower part of the Yakataga Formation. Because the COST well was drilled primarily for geologic information, it was located intentionally in a syncline to reduce the possibility of penetrating significant quantities of hydrocarbons. The well was spudded on July 22, 1975, and plugged and abandoned at a total depth of 5,150 feet $(1,570 \mathrm{~m})$ relative to the rotary Kelly bushing (RKB) on October 10, 1975; various drilling and weather problems had so slowed progress that it was unlikely that the objective portion of the Yakataga Formation could be reached prior to OCS Lease Sale No. 39 , and therefore the participants considered continuation of the project to be uneconomic.

This report expresses all depths in the well in feet below the rotary Kelly bushing (RKB) because that is the unit in which the original measurements were made. These depths may be converted to depths in feet below mean sea level by subtracting 32 feet.

This introduction, the summary and conclusions, and the section on well data were written by G. H. Stewart. J. G. Bolm and J. C. Wills wrote the sections on rock characteristics and geophysical log interpretation and stratigraphy. The sections on paleontology, geophysics, and environmental considerations were written by R. F. Turner, H. H. Waetjen, and F. B. Chmelik, respectively. J. G. Bolm coordinated the overall writing of the report. 


\section{WELL DATA}

\section{Summary of Well Data}

Lease designation: Unleased

Well name and number: Atlantic Richfield Northern Gulf of Alaska COST Well No. 1, OCS 75-60 No. 1

Location:

$$
\begin{aligned}
& x=381,781.66 \\
& y=6,631,345.39
\end{aligned}
$$

Block .1382N - 76E, OCS Map 7-1 (Icy Bay)

Latitude: $58^{\circ} 48^{\prime} \mathrm{N}$

Longitude: $143^{\circ} 06^{\prime} \mathrm{W}$

Classification: Offshore deep stratigraphic test

Elevation: Rotary Kelly bushing 32 feet $(10 \mathrm{~m})$

Water depth: 570 feet $(174 \mathrm{~m})$

Spud date: July 22, 1975

Date total depth reached: September 3, 1975

Completion date: October 10, 1975

Status: Plugged and abandoned

Total depth: 5,150 feet measured depth

Plug-back depth: 651 feet measured depth

Operator: Atlantic Richfield Company

Participants:

Al-Aquitaine Exploration Limited

Amerada Hess Corporation

American Petrofina Exploration Company 


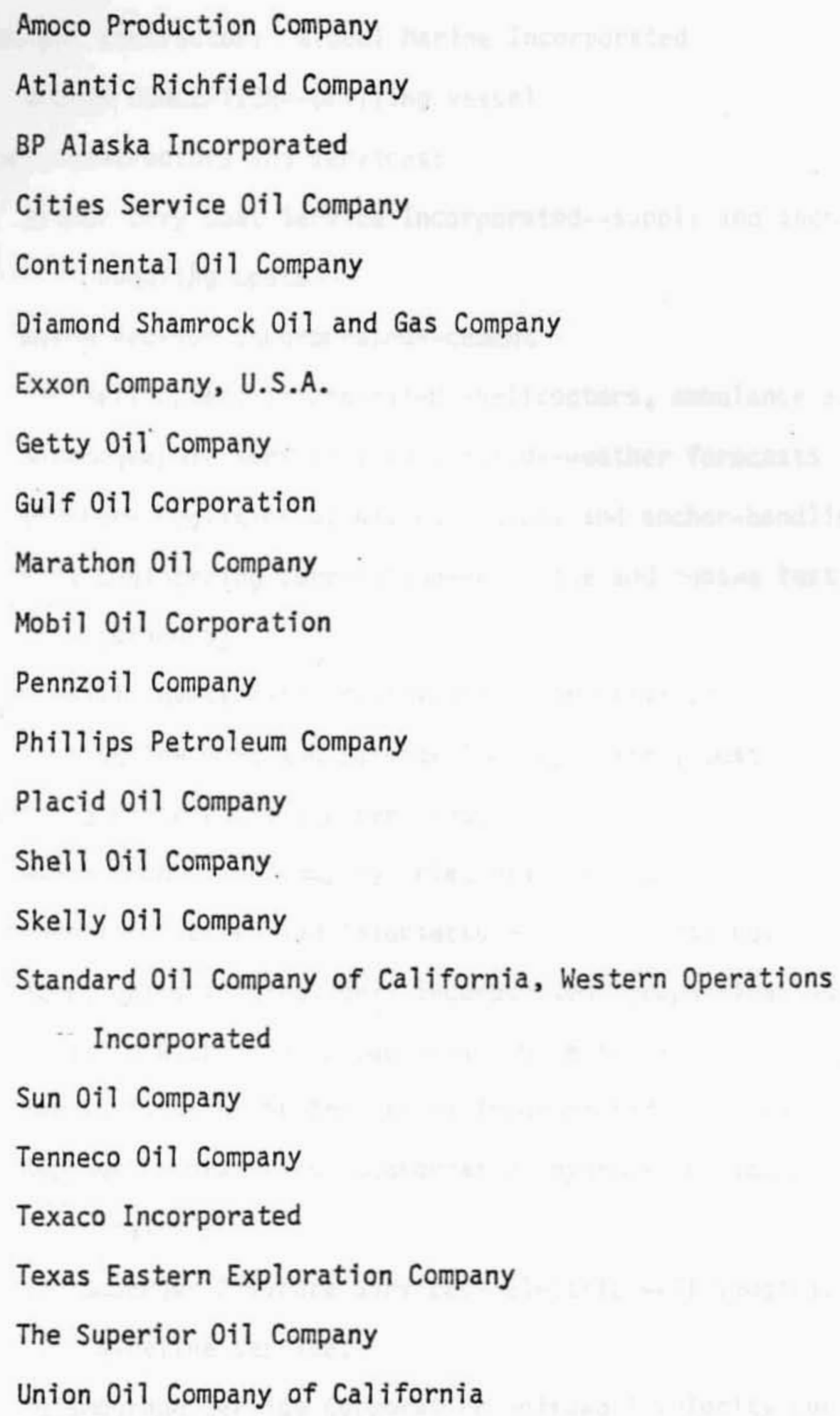


Principal contractor: Global Marine Incorporated

GLOMAR CONCEPTION--Drilling vessel

Support contractors and services:

Arthur Levy Boat Service Incorporated--supply and anchorhandling boats

Byron Jackson Incorporated--cement

ERA Helicopters Incorporated--helicopters, ambulance aircraft

Oceanographic Service Incorporated--weather forecasts

Offshore Logistics of Alaska--supply and anchor-handling boats

Otis Engineering Corporation--wireline and subsea test tree (standby)

0'Neill Investigations--investigation services

Pacific Tow Boat and Salvage Company--safety boat Geoscience contractors and services:

Amoco Production Company--elemental analysis

Anderson, Warren and Associates--micropaleontology

Aquatronics International Incorporated--geophysical survey Atlantic Richfield Company--vitrinite reflectance analysis

Baroid Division NL Industries Incorporated--mud log

Geochem Laboratories Incorporated--hydrocarbon source facies analysis

Schlumberger Offshore Services--electric well logging, wireline services

Seismograph Service Corporation--birdwell velocity survey

Tetra Tech Incorporated--biological survey 


\section{Operationa1 Data}

Mud program: The drilling fluid used in the mud program for the initial 1,000 feet $(305 \mathrm{~m})$ of drilled hole below the ocean floor was salt water. From this point to total measured depth of 5,150 feet a lignosulfonate mud was used. A mud $\log$ was made from measured depths of 1,477 to 5,150 feet. Hole dimensions: A 36 -inch hole was drilled to a depth of 94 feet $(29 \mathrm{~m})$ below the ocean floor (696 feet measured depth), thence a 26 -inch hole to 899 feet $(274 \mathrm{~m})$ below the ocean floor (1,501 feet measured depth), and an 18-inch hole from 899 feet $(274 \mathrm{~m})$ to a total depth of 4,548 feet $(1,386 \mathrm{~m})$ below the ocean floor $(5,150$ feet measured depth).

Open hole tests: No conventional drill stem tests were run. Cores: Neither conventional cores nor sidewa11 cores were taken. Samples: 120 samples were taken at 30 -foot $(9.1 \mathrm{~m})$ intervals from 1,501 to 5,150 feet measured depth.

Geochemical analysis: 60 cutting samples from 1,501 to 5,040 feet measured depth.

Elemental analysis: 7 cutting samples from 1,620 to 5,130 feet measured depth.

Microfossil analysis: 41 cutting samples (all available sample materia1) from 1,500 to 5,150 feet measured depth. Vitrinite reflectance analysis: 19 cutting samples from 1,500 to 5,100 feet measured depth. 


\section{Surveys:}

Geophysical logs: 1,477 to 5,150 feet measured depth.

Dual induction-laterolog--2-inch and 5-inch

Borehole compensated sonic log--2-inch and 5-inch.

Compensated neutron formation density--5-inch only.

Compensated formation density log--5-inch only

Birdwell seismic velocity survey: 1,450 to 5,090 feet measured depth.

Hole deviation: The well was drilled as a vertical hole. At total depth the hole was classified as straight.

\section{Pipe record:}

$\underline{\text { Size }}$

Depth set Hole size Cementing record

30 inch

677 feet 36 inch

$750 \mathrm{sx}$ "G" W/2 $3 \%$ GEL + 1200 SX "G"

37 feet

20 inch

1,473 feet 26 inch $1,475 s \times$ "G" $W / 2$ \%ँ

36 feet GEL + 400 SX "G"

$133 / 8$ inch 5,070 feet 18 inch $2,500 s X$ "G" W/2 $\frac{1}{2} \%$ GEL + 400 SX "G"

31 feet

NOTE: Drill floor 32 feet $(10 \mathrm{~m})$ above mean water level, water depth 570 feet $(174 \mathrm{~m})$.

\section{Operational Problems}

Several factors contributed to slower-than-anticipated progress and led to the abandonment of the well short of geologic objectives:

1. Soft clay bottom. Several attempts and use of a specially 
fabricated base plate were required to seat a guide base. A thin layer of unconsolidated clay, identified in the pre-site high resolution geophysical survey, presented technical difficulties like those in Cook Inlet and off the Mississippi Delta.

2. Difficult drilling and hole control problems. Drilling of unconsolidated deposits containing gravel and boulders slowed the drilling.

3. Adverse weather. One severe storm in September and other weather disturbances caused considerable delays. Severe storms in the fall and winter are to be expected in the Gulf of Alaska. Weather was abnormally severe in September, but over the entire operating period storms were no more frequent or intense than they had been in previous years.

4. Drill ship limitations. The GLOMAR CONCEPTION is not designed to conduct continuous drilling operations under rough sea conditions. She lacks motion-compensating equipment such as has been installed on newer GLOMAR vessels and some other drill ships for improved performance in rough seas.

5. Deep water. Operation in $\mathbf{5 7 0}$ feet of water contributed to delays, especially when diver assistance was needed.

6. Mechanical problems with $133 / 8$-inch casing. Between 670 and 708 feet measured depth a leak and damaged casing in the 13 3/8-inch casing string caused considerable delay and presented a potential obstacle to successful completion of the well. Continued operations would have required an unplanned string of 
casing and eliminated the option of a protective string at some greater depth, thereby reducing flexibility for dealing with problems that might have arisen as drilling proceeded. 


\section{ROCK CHARACTERISTICS AND \\ GEOPHYSICAL LOG INTERPRETATION}

The COST well penetrated a sequence of glaciomarine conglomerate, sandstone, siltstone, and mudstone. Few, if any, clean sandstones were penetrated. Coarse clastic intervals were typically described in the mud log as "conglomerate, unconsolidated, in a matrix of sandstone and siltstone, with pebbles of igneous and metamorphic rock." Siltstone is the dominant fine-grained material, but some "sticky clay" was mentioned in the mud log.

The geophysical-log evaluation of this well includes the derivation of formation porosities, fluid resistivities, water saturations, sand percentages, and lithology (clay- and shaleindicator) crossplots.

Geophysical and mud logs were for the interval from 1,477 to 5,150 feet measured depth.

There were no formation tests, no formation fluids recovered, and no conventional or sidewall cores taken. Therefore, all interpretations of fluid resistivities and rock characteristics have been made on the basis of mud and geophysical logs.

The rocks exhibit poor reservoir potential. The coarser clastic intervals are largely conglomeratic with sandstone, siltstone, and mudstone matrices. Crossplots of sonic, neutron, and density data indicate a high clay or mud content and low effective porosities. 
According to the S.P. log coarse clastic rocks comprise 894 feet $(272 \mathrm{~m}), 24$ percent of the total logged section. The coarse clastic intervals are defined by S.P. deflections of 20 to 40 millivolts. The intervals are generally not "blocky" S.P. deflections, but are of a "sawtooth" nature which reflects the conglomeratic nature of the material. Thickness of the units averages 50 feet $(15 \mathrm{~m})$ and ranges from 6 to 309 feet $(2$ to $94 \mathrm{~m})$. Apparent porosities derived from the density log average 24.5 percent; those derived from sonic and compensated neutronlogs average 40 percent because of high clay or mud content and the presence of carbonate cement. Effective porosities are probably very low (see figs. 2 and 3 ).

Formation water resistivities derived from the S.P. log are thought to be unreliable because of the low permeability of sandy intervals. A plot of deep-induction resistivity versus densityderived porosity on $\log -\log$ paper indicates that all sandy intervals are 100 percent water-saturated, and extending the $R_{0}$ line to 100 percent porosity indicates formation water resistivities are in the range of 0.1 to 0.3 ohm-meters. This range seems rather high for a marine environment; the high clay or mud content and the presence of carbonate cement and resulting low permeability may have hampered accurate $R_{W}$ determinations. 


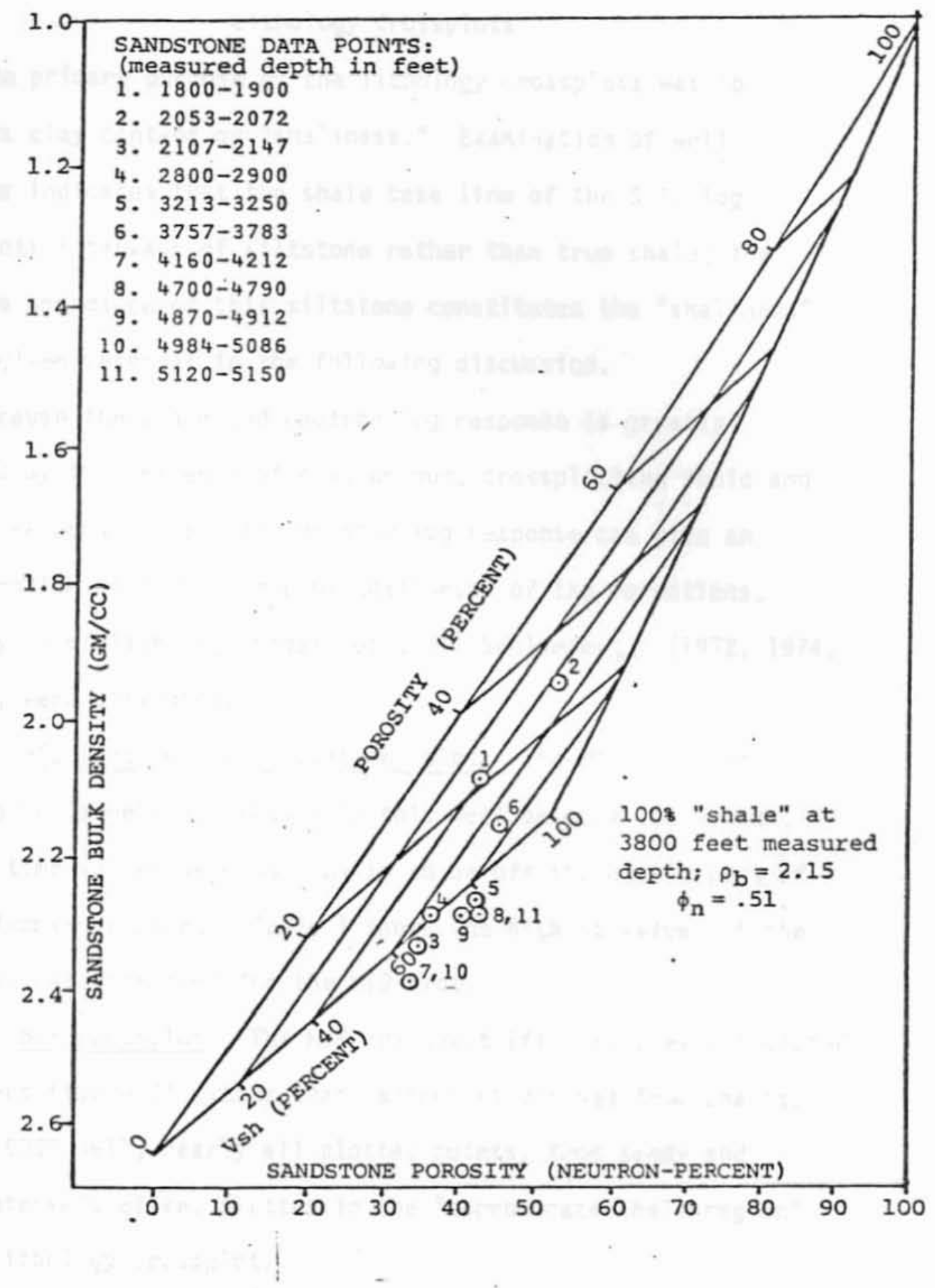

Figure 3. Neutron-density crossplot for Atlantic Richfield Northern Gulf of Alaska COST Well No. 1 (Method from Schlumberger, 1972). 


\section{Lithology Crossplots}

The primary purpose of the lithology crossplots was to estimate clay content or "shaliness." Examination of well cuttings indicates that the shale base line of the S.P. log represents intervals of siltstone rather than true shale; the relative abundance of this siltstone constitutes the "shaliness" of any given interval in the following discussion.

Because the sonic and neutron log response is greatly affected by the presence of clay or mud, crossplotting sonic and neutron response versus the density $\log$ response can give an approximation of the "degree of shaliness" of the formations. Three types of lithology crossplots, all Schlumberger (1972, 1974) methods, were attempted:

1. MID (matrix identification) plot. The MID plot was found to be largely unworkable in this well because the sonic. transit time values were so slow as to be off the usable part of the Schlumberger chart. Table 1 shows the high $\Delta t$ values of the crossplot data intended for the MID plot.

2. $M-N$ crossplot. The $M-N$ crossplot (fig. 2) uses calculated parameters (table 2) rather than parameters derived from charts. For the COST well, nearly all plotted points, from sandy and silty intervals alike, plotted in the "approximate shale region" of the lithology crossplot.

3. Neutron-density crossplots. Neutron-density crossplots are useful as clay or "shaliness" indicators. The plotted points 
Table 1. MID Lithology Crossplot Data for Atlantic Richfield Northern Gulf of Alaska COST Well No. 1

\begin{tabular}{|c|c|c|c|c|c|c|c|}
\hline & POINT & $\begin{array}{l}\text { MEASURED DEPTH } \\
\text { (feet) }\end{array}$ & $\begin{array}{c}\text { ACNL } \\
\text { (sandstone) }\end{array}$ & PB & $\Delta r$ & $\Delta t m a(a)$ & pma (a) \\
\hline 1 & (sand) & $1875-80$ & 36 & 2.25 & 135 & off chart & 2.78 \\
\hline 2 & (shale & $1930-40$ & 31 & 2.4 & 129 & off chart & 2.81 \\
\hline 3 & (shale) & $2030-40$ & 36 & 2.4 & 128 & off chart & 2.87 \\
\hline 4 & (sand) & $2130-40$ & 33 & 2.27 & 132 & off chart & 2.75 \\
\hline 5 & (shale) & $2345-55$ & 36 & 2.4 & 130 & of $f$ chare & 2.88. \\
\hline 5 & (sand) & $2505-10$ & 45 & 2.2 & 145 & of $f$ chart & 2.88 \\
\hline 7 & (shale) & $2690-2700$ & us & 2.27 & 144 & off. chart & 2.92 \\
\hline & (sand) & $2835-45$ & 38 & 2.15 & 145 & off chart & 2.72 \\
\hline 9 & $(\operatorname{silt})$ & $2928-30$ & 4 & 2.59 & 81 & 72.5 & 2.58 \\
\hline 10 & $($ shale) & $3040-50$ & 36 & 2.35 & 95 & 49 & 2.88 \\
\hline 11 & (sand) & $3230-35$ & 42 & 2.25 & 142 & of $f$ chart & 2.87 \\
\hline 12 & (shale) & $3495-3500$ & 36 & 2.38 & 115 & off chare & 2.87 \\
\hline 13 & (shale) & $3665-70 /$ & 39 & 2.35 & 130 & off chart & 2.89 \\
\hline 14 & (sand) & $3770-80$ & $\therefore \quad 45$ & 2.19 & 241 & off chart & 2.87 \\
\hline 15 & (shale) & . $4000-4010$ & 38 & 2.36 & 119 & off chart & 2.88 \\
\hline 15 & (sand) & $4190-4200$ & 30 & 2.41 & 121 & off chart & 2.81 \\
\hline 17 & (shale) & $4355-75$ & 37 & 2.38 & 206 & 57 & 2.88 \\
\hline 18 & (shale) & $4540-50$ & 48 & 2.17 & 145 & off chart & off chart \\
\hline 19 & (shaje) & $4640-50$ & 45 & 2.17 & 245 & off chart & 2.87 \\
\hline 201 & (shale) & $4800-05$ & so & 2.2 & 132 & off chart & off chart \\
\hline 21 & (sand) & $4890-900$ & 40 & 2.2 & 119 & off chart & 2.80 \\
\hline 22 & (sand) & $5005-15$ & 33 & 2.42 & 205 & 6s & 2.85 \\
\hline 23 & (shale) & $5105-25$ & so & 2.25 & 130 & off chart & of $f$ chart \\
\hline 24 & (saind) & $5130-40$ & $\begin{array}{r}42 \\
\end{array}$ & 2.28 & 130 & off chart & 2.90 \\
\hline
\end{tabular}


Table 2. Calculated Lithology Crossplot Data for Atlantic Richfield Northern Gulf of Alaska COST Hell No. 1

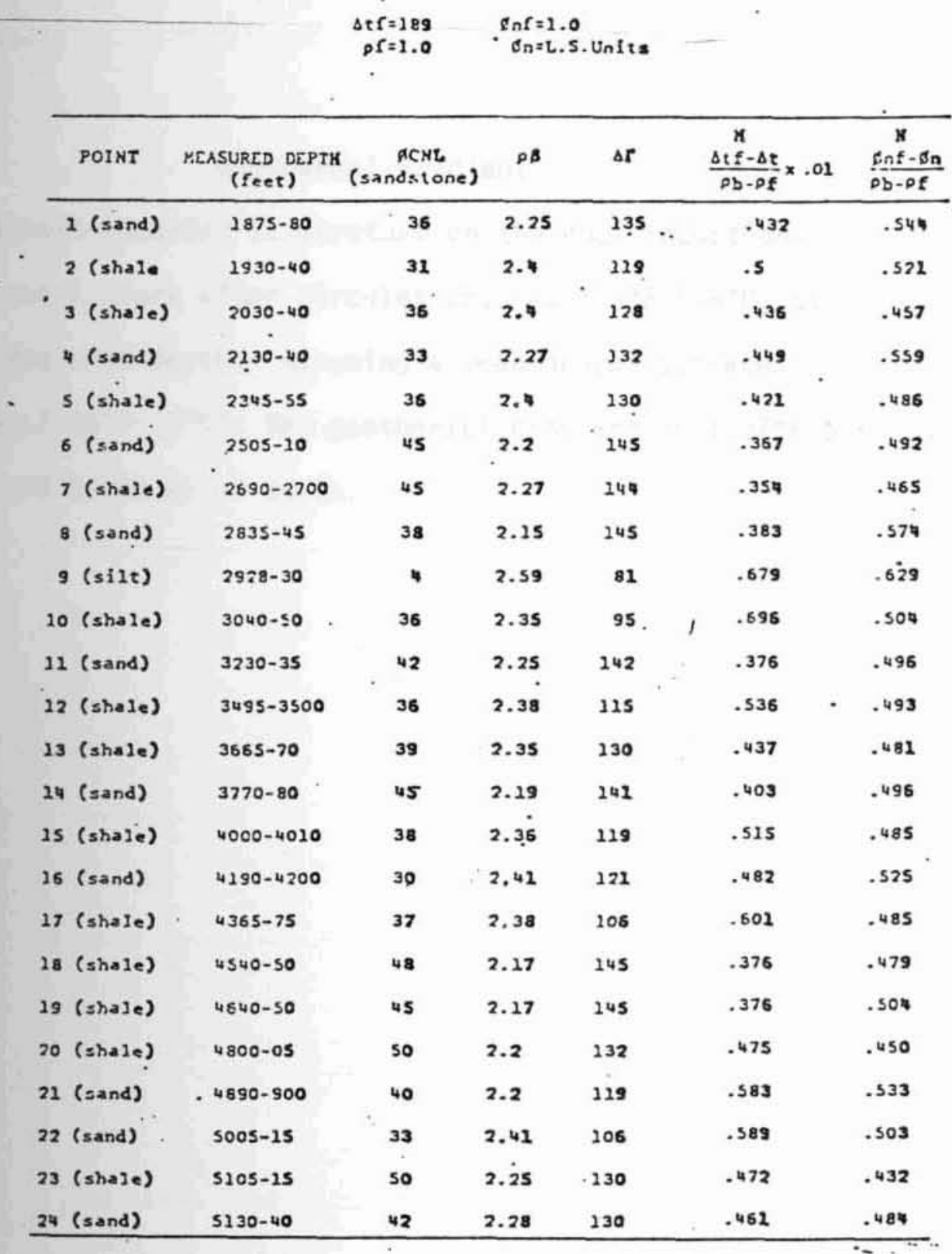


indicate percent "shale" as a percentage of total volume and effective porosity. As can be seen from the crossplot of the coarse clastic intervals (fig. 3 ), $V$ shale ranges from 35 to 95 percent, and effective porosities are generally less than 10 percent.

\section{Geothermal Gradient}

The highest recorded temperature on the dual inductionlaterolog, run 7 hours after circulation, was $115^{\circ} \mathrm{F}\left(46^{\circ} \mathrm{C}\right)$ at 5,150 feet measured depth. Assuming a mean annual surface temperature of $45^{\circ} \mathrm{F}\left(7^{\circ} \mathrm{C}\right)$, the geothermal gradient is $1.37^{\circ} \mathrm{F}$ per 100 feet $\left(2.48^{\circ} \mathrm{C} / 100 \mathrm{~m}\right)$ of depth. 


\section{STRATIGRAPHY}

The COST well was located in 570 feet $(174 \mathrm{~m})$ water depth and spudded in unconsolidated Holocene glacial deposits. The top of the geophysically logged interval at 1,477 feet measured depth is in the Yakataga Formation, and the well was still in the Yakataga Formation at total depth.

The Yakataga Formation has a total thickness of at least 16,500 feet $(5,000 \mathrm{~m})$ and ranges in age from early or middle Miocene to Pleistocene. It overlies the 01 igocene to late Miocene Poul Creek Formation which is composed predominantly of fine-grained clastic marine rocks which constitute a favorable source for petroleum. Sandstones in the lower part of the Yakataga Formation immediately overlying the Poul Creek Formation are thought to have the greatest potential for oil accumulation in the Yakataga Formation.

The COST well was located in a syncline identified by seismic data and penetrated only material eroded from nearby structures in the OCS sale area; no useful lithologic information concerning the prospective section within such structures was obtained from the COST well.

The nearest onshore wells are located in structurally complex areas, and therefore a reliable seismic tie cannot be established between the COST well and the nearest onshore wells.

The SOCAL Riou Bay No. 1 well, approximately 60 miles (95 km) east of the COST well, seems to be on strike stratigraphically 
with the COST well; both are in a single area of relatively simple structure, and coherent seismic reflections can be followed between the two wells except where seismic data are lacking near the shoreline. Lithologic similarities between the two wells and a reasonable projection of the seismic tie suggest that the section penetrated by the COST well is the approximate stratigraphic equivalent of the upper 4,000 feet $(1,200 \mathrm{~m})$ of the SOCAL Riou Bay No. 1 well.

Age determinations were based upon examination of foraminiferal samples (see paleontology section this report).

\section{Lithologic Description}

No conventional or sidewall cores were taken in the well. All descriptions of 1ithology are from examination of cuttings or $\log$ interpretation.

A11 recovered cuttings from the COST well were from the Yakataga Formation and consisted of various poorly indurated mixtures of clay, silt, sand, and gravel. Clay, present as a minor component, is mineralogically the same as a siltstone which is encountered in all cuttings from the well. This siltstone is variously clean, sandy, or conglomeratic at different depth intervals; where sand or gravel predominates the rock becomes a sandstone or conglomerate in which the siltstone forms the matrix.

The siltstone is white or gray except where stained brown by 
iron oxide; it is friable and has been cemented to various minor degrees by calcium carbonate. The silt fraction, predominantly quartz, includes minor amounts of unweathered amphibole, biotite and other minerals.

Sand grains range from very fine to very coarse on the Wentworth scale and are predominantly quartz; unweathered rock fragments, amphibole, and mica occur in the sand fraction. Quartz occurs commonly as clear or milky monocrystalline grains which are generally subrounded to subangular and occasionally subhedral. Sand-size rock fragments are almost exclusively metamorphic, largely quartzite and argillite but include minor greenstone and chlorite schist, and such fragments together with amphibole are more common in the coarser than in the finer sand grades. The sand fraction contains biotite, muscovite, and very small amounts of unweathered epidote, chlorite, garnet, and calcite.

The gravel fraction consists largely of metamorphic rock fragments and some sedimentary rock fragments. The same metamorphic rock types occur in the gravel as in the sand fraction, and wellindurated, noncalcareous quartzose sandstone is the prevalent sedimentary rock type. Igneous rocks are rare in the gravel. Individual clasts are generally subangular to rounded, and al though the largest observed are of pebble size, larger clasts may exist in the sediment; clasts larger than pebble size are not likely to come to the surface as cuttings. Unstable minerals in 
the gravel fraction are unweathered, and some clasts are marked with glacial striae.

The lithologies of rock fragments in the strata penetrated by the COST well are consistent with a source in the ChugachSt. Elias mountain system north of the well site. The morphology of quartz sand grains is suggestive of plutonic provenance, and although some such grains have likely been derived immediately from a sedimentary source, much of the quartz sand is probably derived from granitic terrane in the source area. The unweathered condition of unstable minerals in the rock penetrated by the COST well indicates rapid erosion and deposition.

The rocks penetrated by the well were apparently deposited by normal marine and glaciomarine processes. Much of the finer material was probably deposited by marine currents, and all of the coarser and some of the finer material was undoubtedly rafted to the site of deposition by glacial ice.

After deposition the sediments were cemented to various minor degrees by calcium carbonate. An obvious potential source for that cement is the tests of various marine invertebrates. 


\section{PALEONTOLOGY}

Concentrated foraminiferal residues prepared for participants in the COST well and dril1 bit cuttings washed over a 150-mesh sieve were examined at 30 -foot intervals from 1,500 to 5,150 feet measured depth. The taxonomic and paleoecologic interpretations follow Todd and Low (1967), Loeb1ich and Tappan (1953), Echols (1973), and Ingle (1973).

The subarctic microfaunal assemblage identified in the COST well is essentially the same as the modern Gulf of Alaska microfauna. The assemblage has persisted with few changes since the Pliocene. The excellent preservational state of the fossil material and the presence of predominantly sinistrally coiled populations of Globigerina pachyderma suggest a middle to late Pleistocene age for the sampled interval.

The overall faunal assemblage is composed of recurring neritic and upper bathyal elements defined by the presence and relative abundance of diagnostic foraminiferal species. Ecological gradations, the presence of reworked fossil material, and sample contamination from up-hole caving often serve to modify these two basic elements.

The inner neritic fauna is dominated by several species of Elphidium, particularly E. clavatum, E. oregonense, E. bartletti, E. frigidum, and Protoelphidium orbiculare, and Buccella frigida and B. inusitata.

The more diverse middle neritic fauna contains most of the 
inner neritic species as well as Cassidulina limbata, $\underline{\text { C. norcrossi, }}$

c. teretis, Karreriella baccata, Cibicides fletcheri,

Uvigerina juncea, Nonionella auricula, Nonionellina labradorica,

Trifarina angulosa, and Globigerina pachyderma.

The outer neritic and upper bathyal faunas contain many of the middle neritic species as well as Pullenia salisburyi,

Bolivina spp., Epistonomella pacifica, and Cassidulina californica. Upper bathyal faunas are dominated by Epistominella pacifica,

E. cf exigua, Eilohedra levicula, Uvigerina peregrina.

The transgressive upper bathyal pulses seen in the COST well at $1,500,2,130,2,490,2,790,3,300,3,780,4,620$, and 5,130 feet measured depth are probably both glacioeustatic and tectonic in origin. 


\section{GEOPHYSICS}

The COST well was located in a syncline as mapped from common-depth-point seismic data. A single-channel sparker survey run by the University of Washington Research Vessel THOMAS G. THOMPSON in 1974 detected no evidence of slides or near-surface faults in the well area (Carlson and others, 1975).

Interval velocities and average velocities were calculated for rocks at various depths in the COST well from the borehole compensated sonic log (fig. 4). 
1 WAY TIME (MILLISECONDS)
VELOCITY (FEET/SEC)

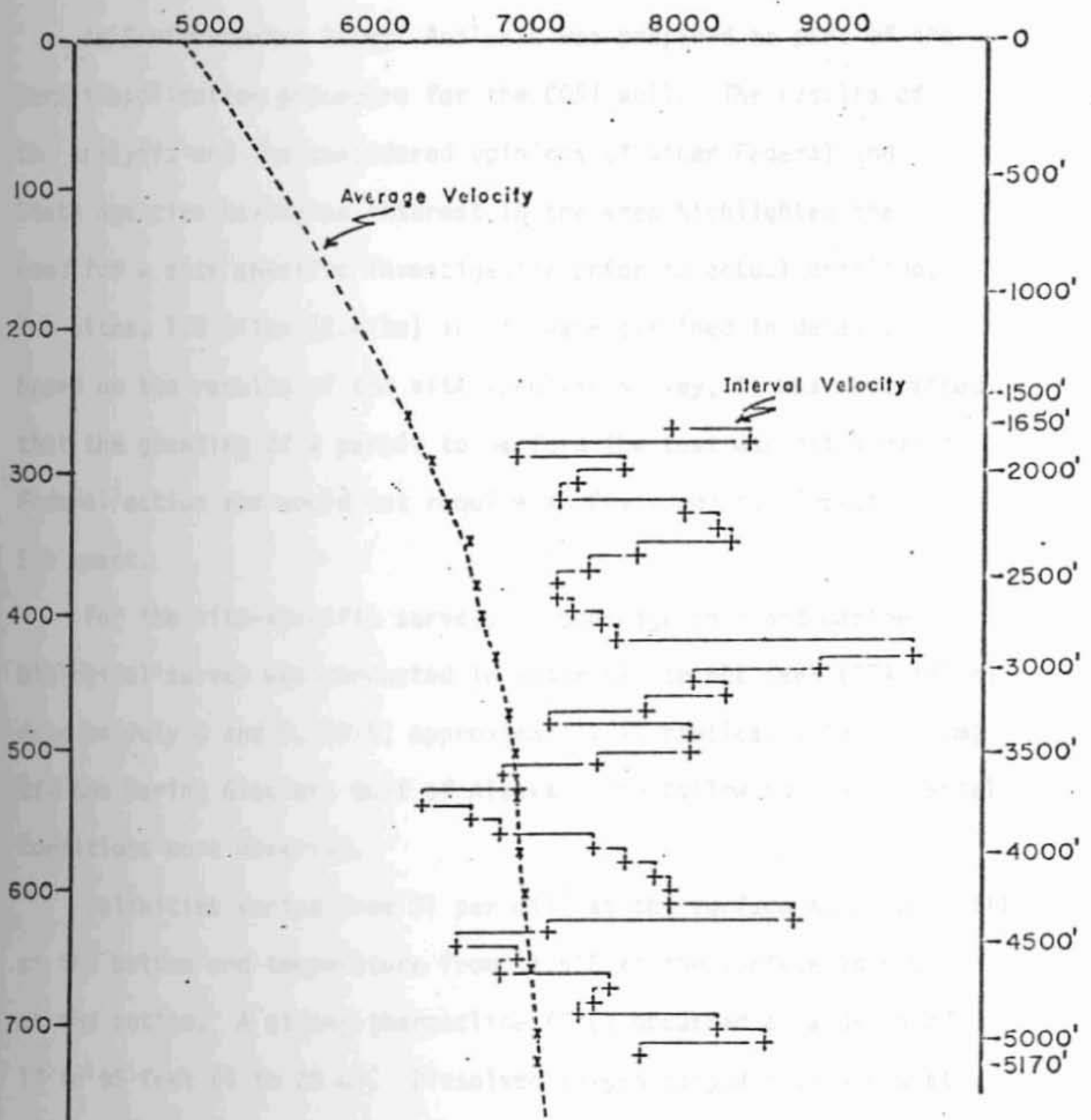

800

Figure 4. Velocity derived from sonic log for Atlantic Richfield Northern Gulf of Alaska COST Well No. 1. 


\section{ENVIRONMENTAL CONSIDERATIONS}

An Environmental Impact Analysis was prepared as part of the permit-application procedure for the COST well. The results of the analysis and the considered opinions of other Federal and State agencies having an interest in the area highlighted the need for a site specific investigation prior to actual drilling. Two sites, 1.5 miles $(2.4 \mathrm{~km})$ apart, were examined in detail. Based on the results of the site-specific survey, it was determined that the granting of a permit to perform the test was not a major Federal action and would not require an Environmental Impact Statement.

For the site-specific survey, an oceanographic and marine biological survey was conducted in water 570 to 602 feet (174-184 m) deep on July 8 and 9, 1975, approximately 14 nautical miles (26 km) off the Bering Glacier, Gulf of Alaska. The following environmental conditions were observed.

Salinities varied from 31 per mill at the surface to 33 per mill at the bottom and temperature from $11.5^{\circ} \mathrm{C}$ at the surface to $6^{\circ} \mathrm{C}$ at the bottom. A strong thermocline $\left(3^{\circ} \mathrm{C}\right)$ occurred at a depth of 13 to 95 feet ( 4 to $29 \mathrm{~m}$ ). Dissolved oxygen ranged from $4 \mathrm{ppm}$ at the surface to almost $6 \mathrm{ppm}$ near the bottom. The maximum seiche disk reading was 9 meters.

Profiles of the sea floor were made with an echo sounder. Bottom sediments consisted principally of glacially-derived fine gray silts and clays at both sites. Pebbles and small cobbles 
occurred at one site. Bottom sediments contained 62 to 65 percent solids and an average of 4 percent iron, $74 \mathrm{ppm}$ chromium, and $289 \mathrm{ppm}$ barium based on dry weight.

The major phytoplankton populations consisted of diatoms (Chaetoceros, Corethron, Thalassiothrix) and dinoflagellates (Ceratium, Peridium). The predominant zooplankta were copepods (Calaneis, Metridia, Oithona).

Six grab samples contained a predominance of polychaete worms (Nothria) and bivalve mollusks (Astarte). The species diversity was somewhat low $\left(H^{\prime}=1.27\right.$ to 2.3 ; number of species from 6 to 12; total number of species for all samples was 22).

The bucket-dredge sample taken from one site contained a predominance (by biomass) of brachiopods (Laqueus), bivalve mollusks (Astarte) and polychaete worms. Polychaéte worms made up 48 percent and moliusks 24 percent of the species. The species diversity was moderate $\left(H^{\prime}=2.8\right.$; number of species was 21$)$ and considerably higher than that taken by otter trawls.

The otter-trawl samples indicated that the dominant epibenthic species at both sites was the brittlestar Ophiura sarsii. The second most dominant species was the small cushion star Ctenodiscus crispatus at one site and the shrimp Crangon abyssorum at the other site. The otter-trawl collection at one site contained (by species composition) 22 percent echinoderms, 19 percent polychaetes, 16 percent crustaceans, 14 percent mollusks, 11 percent fishes; 5 phyla made up the remaining 
18 percent. Echinoderms contributed 79 percent, crustaceans 15 percent, and several remaining phyla contributed 6 percent of the total invertebrate biomass. The deposit-feeding brittlestar Ophiura sarsii alone contributed at least 40 percent of the epibenthic invertebrate biomass. The trophic structure is represented by 50 percent filter feeders, 22 percent deposit feeders, 19 percent carnivores, 6 percent scavengers, and 3 percent ectoparasites, reflecting the availability of large amounts of detritus as the prime energy source. Ten captured teleost fish (6 species) were pricklebacks (family Stichaedae) and eelpouts (family Zoarcidae). Typical of cold waters, the benthic fauna is not particularly diverse. Relatively few species and individuals of commercial importance were found.

The results of the pre-drilling site-specific survey was consistent with the results of previous studies.

Environmental monitoring activities on the drillship during operations tended to confirm the conditions predicted in the environmental analysis. Sea state, storms, and currents were within the expected limits.

The information gained from current meter measurements made during drilling was used to plan a 1-year-later follow-up survey, which will look for residual habitat changes possibly related to drilling.

In summary, no long term adverse environmental impacts are considered to have resulted from the drilling operations, and 
short-term effects appear to have ceased. The follow-up survey will help to confirm this conclusion or to identify specific problem areas. 


\section{SUMMARY AND CONCLUSIONS}

The COST well was located on an off-structure site selected to minimize the possibility of penetrating zones bearing significant quantities of hydrocarbons. The well was intended to reach a total measured depth of 16,500 feet so as to penetrate the rocks of primary interest, the lower part of the Yakataga Formation, an interval which in the test area is below 10,000 feet $(3,000 \mathrm{~m})$. The entire interval that was logged and sampled consisted of marine and glaciomarine clastic rocks in the upper part of the Yakataga Formation and of probable middle to late Pleistocene age. Because the total depth reached was only 5,150 feet, the COST well provided no lithologic information concerning potentially productive horizons.

Sandstones are not of reservoir quality owing to the presence of interstitial silt and clay and carbonate cement. This fact, determined by sample analysis, was confirmed by the electric logs which showed high "shaliness" in all the sandy intervals. The logs do not indicate the presence of any hydrocarbons. An organic geochemical study of samples from the well indicates that the entire interval penetrated has an immature source character and probably has not generated any liquid hydrocarbons. 


\section{REFERENCES}

Carlson, P. R., Bruns, T. R., and Molnia, B. F., 1975, Submarine slides and nearsurface faults, northern Gulf of Alaska:

U. S. Geol. Survey Open-File Rept. $75-504,6$ p., 1 pl., scale 1:500,000.

Echols, R. J., 1973, Foraminifera, leg 19, Deep Sea Drilling Project, in Creager, J. S., Scholl, D. W., and others, Initial reports of the Deep Sea Drilling Project: Washington, D. C., U. S. Govt. Printing Office, v. 19 , p. $727-731$.

Ingle, Jr., J. C., 1973, Neogene foraminifera from the northeastern Pacific Ocean, leg 18, Deep Sea Drilling Project, in Klum, L. D., von Huene, R., and others, Initial reports of the Deep Sea Drilling Project: Washington, D. C.,.

U. S. Govt. Printing Office, v. 18, p. 526-527.

Loeblich, Jr., A. L., and Tappan, Helen, 1953, Studies of arctic foraminifera: Misc. Colln. Smithsonian Inst., v. 121, 150 p. Schlumberger Limited, 1972, Log interpretation--volume 1,

Principles: New York, Schlumberger, 112 p.

1974, Log interpretation--volume 2, Applications: New York, Schlumberger, $116 \mathrm{p}$.

Todd, Ruth, and Low, Doris, 1967, Recent Foraminifera from the Gulf of Alaska and southeastern Alaska: U. S. Geol. Survey Prof. Paper 573-A, P. Al-A46. 